\title{
Role of Problematic Internet Use, Sense of Belonging and Social Appearance Anxiety in Facebook Use Intensity of University Students
}

\author{
Zeliha Tras ${ }^{1}$, Kemal Öztemel ${ }^{2} \&$ Umay Bilge Baltaci ${ }^{1}$ \\ ${ }^{1}$ Education Faculty, Necmettin Erbakan University, Konya, Turkey \\ ${ }^{2}$ Gazi Education Faculty, Gazi University, Ankara, Turkey \\ Correspondence: Zeliha Tras, Education Faculty, Necmettin Erbakan University, Konya, Meram Yeniyol 42090, \\ Turkey.
}

Received: April 10, 2019

doi:10.5539/ies.v12n8p1

\author{
Accepted: May 16, 2019 \\ Online Published: July 29, 2019
}

URL: https://doi.org/10.5539/ies.v12n8p1

\begin{abstract}
The aim of this study was to examine the role of problematic internet usa, sense of belonging and social appearance anxiety in facebook use intensity of university students. The sample of the study consisted of 484 (332 female, 68.6\% and 152 male 31.4\%) different faculties of various universities of Konya. Problematic Internet Use Scale, General Belongingness Scale, Facebook Intensity Scale, The Social Appearance Anxiety Scale, Personal Knowledge Form were used in the study. Pearson Correlation Product Conduct and multiple regression analysis were used to analyze the data. According to the findings of the study, There was a significant positive relationship between the mean scores of the participants on the Facebook Intensity Scale and the mean scores of the Problematic Internet Use Scale and the Social Appearance Anxiety Scale. Regression analysis examined shows that social appearance anxiety and problematic internet use and general belonging sense average scale scores were significantly prediction of Facebook İntensity Scale Scores. The results of the research were discussed within the framework of the literature. Based on the findings of the research, comments and suggestions were developed.
\end{abstract}

Keywords: Facebook intensity, problematic internet use, social appearance anxiety, sense of belonging

\section{Introduction}

The internet enables millions of people to do a range of things like communicating, researching, executing business transactions, accessing to international libraries, shopping, or making vacation plans with ease (Young, 1999; Thatcher \& Goolam, 2005). The Internet is used not only for researching on search engines, but also for communicating through online forums, interacting with environment, and socializing. Many people put an online (the Internet-based) social life, that enables myriad possibilities which are almost impossible in offline world, in the center of their lives (Stieger, Burger, Bohn, \& Voracek, 2012). It is thought that social media platforms contribute largely to the forming of the Internet-based social life.

Since their earliest days, social media platforms like Instagram, MySpace, and Facebook have attracted millions of users, and many of them, whether personal or corporate, have integrated these platforms to their daily applications (Boyd \& Ellison, 2007). It is stated that being one of the most popular social media platforms, Facebook has approximately 2.20 billon active users monthly, and 1.45 billion daily (Facebook, 2018). The number of monthly active mobile user is 1.66 billion, and desktop user is 1.57 billion. According to the review of Social Report, Facebook users are $52 \%$ female, and $47 \%$ male. $87 \%$ of online users aged 18-29 use Facebook (Social Report, 2018).

People are required to provide some personal information when they compose their profiles in Facebook (Al-Dheleai \& Tasir, 2015). Facebook enables users to create a profile on which they can share information about themselves like profession, religion, political view, favorite movies, and even the most liked artists (Hughes, Rowe, Batey, \& Lee, 2012). Facebook enables local and national businesses and establishments like restaurants, bars, cafes, sport teams, artists, health and fitness centers, and even politicians to create pages that users can add to their profiles and interact with them. Also, users can choose to share this information with their friends on news feed (Gangadharbatla, 2008). In addition to this, users can use social media platforms like Facebook to interact with people they meet in their daily life and/or to meet and interact with new people (Öztemel \& Traş, 2017).

Enabling to communicate and share interests with other individuals in adolescence and emerging adulthood, 
Facebook is one of the most popular social networks in which adolescents and emerging adults communicate with each other (Santrock, 2012). However, it should be remembered that despite the positive results that Facebook yields, of course there are certain negative results. For example it was find positive correlations between Facebook intensity and both fear of missing out and smartphone addiction in a study (Tras \& Oztemel, 2019). Kuss, Griffiths, Karila, and Billieux (2014) state that one of these negativities is problematic Facebook use or danger of Facebook addiction, in other words. Also, due to some researches, it is thought that Facebook use is related to problematic Internet use (Kittinger, Correia, \& Irons, 2012).

Studies on Facebook that is both popular and has an important share in social networking platforms are still inadequate (Kittinger, Correia, \& Irons, 2012). For example, some researches on online platforms focus on problems like Internet addiction, problematic Internet use, misuse of the Internet by adolescents and young adults, and report that especially university students display problematic Internet use at varying rates like $8 \%$ and $50 \%$ (Anderson, 2001; Young, 1996; Watson, 2005). In other words, most of the previous studies focus on general Internet use instead of use of social media applications like Facebook. This situation actually suggests that as availability of social sharing platforms like Facebook increases, it also contributes to problematic Internet use (Kittinger et al., 2012).

Problematic internet use is defined as the situation in which the individual's internet use is impairing in important areas like business and family, and she/he fails to control this (Kim \& Davis, 2009). According to Ceyhan (2011), problematic Internet use is used to indicate excessive use of the Internet and the effects of problems that stem from it. Also, it can also be defined as the situation in which the individual cannot control Internet use, and as a significant distress and/or impairment (Shapira, Goldsmith, Keck, Khosla, \& McElroy, 2000).

Davis (2001), who distinguishes between general and specific problematic internet use states that specific problematic Internet use expresses online activities like online pornography or online gambling, and behaviors focusing on certain topics like exorbitance of abovementioned activities. On the other hand, Davis emphasizes that general problematic Internet use especially includes general and multi-dimensional excessive use without an aim. Shapira et al. (2000) state that there are studies relating problematic Internet use with serious problems and malfunctions, and for this reason it is unknown if these kind of behaviors represent bottom layer of another psychiatric disorder or malfunction. However, it is stated that problematic Internet use is a multi-dimensional problem that causes negative results and hardships in business, school, and social life of the individual, and that displays cognitive and behavioral symptoms (Anandarajan, Simmers, \& Teo, 2014; Beard, 2005).

Notwithstanding that many researches have been conducted on problematic Internet use, the number of researches that examine the relationship of Facebook use and problematic Internet use is very scant. When these researches are examined, certain relationships are found between Facebook or social media use and problematic Internet use. For example, Kittinger et al. (2012) emphasize that intense use of Facebook might contribute to the severity of the symptoms related to Internet addiction. In the research, they report that individuals, who have higher scores in problematic Internet use, use Facebook more, and display more problems related to Facebook use like feeling social pressure, being late, waste of time, and spending a lot of time. In the research, it is concluded that Facebook use contribute to problematic Internet use. In another research, Blachnio, Przepiorka, Senol-Durak, Durak, and Sherstyuk (2017) find that Facebook addiction has a positive relationship with Internet addiction. Likewise, Blachnio and Przepiorka (2016) find relationships between Facebook addiction, Facebook intensity, and Internet addiction. These researches show that there might be a relationship between intense use of Facebook and Internet addiction. In this context, determining the possible relations between intense Facebook use and problematic Internet use can be useful.

Also, it can be said that problematic Internet use causes losing touch with reality, isolating from the world, and depriving from sense of belonging (Morahan-Martin \& Schumacher, 2003). Maslow (1954) argues that main needs should include more abstract ones like emotional safety, and sense of belonging as well as physiological ones like food, water, and sheltering (Brown, 2012; Maslow, 1954). Sense of belonging is a need that comes from the birth. This need begins with the desire of belonging to a family, and continues with groups, sport clubs, fraternities etc., and results with the need of belonging to a flag, and a nation (Akbaba, 2005; Cüceloğlu, 2002). Sense of belonging is a component of a person's bonding to the people, places and wares around her/him (Hagerty, Lynch-Sauer, Patusky, Bouwsema, \& Collier, 1992). For this reason, belonging is a need that is required to be met in the family, in the neighborhood, and in the school (Akbaba, 2005). Individuals feel alone when they cannot meet this need (Cüceloğlu, 2002). Belonging is a need that can be met within interpersonal relations. According to belonging theory, individuals are directed to develop and maintain positive social relations in order to feel sense of belonging (Grieve, Indian, Witteveen, Tolan, \& Marrington, 2013). While some individuals need less meaningful relations and bonds in order to meet this need, some might need more meaningful relations and bonds (Duru, 
2015). An individual who feels belonging to the society feels her/himself as a part of that society (Alptekin, 2012). For this reason, belonging appears as a concept that takes understanding to forefront in an individual's relationship with others (Özkan, 2015). Sense of belonging, being cared and tended, being understood, being accepted, or feeling belonging to a group or system forms the basis of personality perception (emotion). Developing this base is important especially for the young (Leake, 2007). When the individual is rejected or excluded from the society, she/he gets stressed. All kinds of situations, in which she/he can be rejected or cannot look attractive to the others, threaten the sense of belonging (Burger, 2006).

Being a transition period between adolescence and adulthood, young adult period is thought to have a unique nature in terms of variables like body image, and body acceptance (Kılıç, Mammadov, Koçhan, \& Aypay, 2018). Also, it is thought that in young adulthood individuals have anxieties for having an impact on social environment and one of these is about social appearance (Ülkü, 2017). Young adults' way of coping with body image and anxiety about social appearance is one of the factors that directly influence identity development and their close ties (Özteke-Kozan \& Hamarta, 2017).

Social appearance anxiety is another kind of social anxiety, and is defined as the anxiety and stress that individuals experience while their physical appearance is assessed by other people (Hart et al., 2008). According to Hart et al. (2008) social appearance anxiety is a broad notion that includes features determining face shape like skin tone, nose shape, eye shape, and smile as well as physical features like individual's height, weight, muscle structure and body shape. When it is considered that social share websites like Facebook are important in terms of being platforms in which the individual displays her/himself, is liked by others, and accordingly physical appearance is important, it is thought that Facebook use is related with social appearance anxiety. In this sense, when direct and indirect researches about Facebook use and social appearance anxiety are reviewed, certain relationships are found, albeit limited. For example, in the research conducted by Altındiş et al. (2017) it is concluded that $20 \%$ of the participants have anxiety about being liked in Facebook posts. Also, it is found that there are anxieties like feeling uncomfortable because of one's appearance, being concerned when people do not want to spend time with them, and thinking that their appearance would make difficult their life. Vannucci, Flannery, and Ohannesian (2017) find that individuals using more social media display higher depressive symptoms and anxiety disorders. In another study (Andreassen et al., 2016), it is found that individuals, 16-88 age range, who use social media in a degree that creates addiction have higher anxiety levels. In the research conducted by Campisi et al. (2012) participants state that excessive Facebook use makes them anxious and, because of this anxiety they retard friendship requests. Also, in some other researches (Caplan, 2007, McCord, Rodebaugh, \& Levinson 2014, de Vries et al., 2018) it is thought that problematic Internet use and Facebook use is related with social anxiety.

Nesi and Prinstein (2015) states that when the individual takes unwanted feedbacks from others or faces with unwanted social comparisons, she/he might have anxiety and intense social media use might cause self-assessment, and this situation might function as stress source. In this context, in the light of aforementioned explanations and researches, examining the relationship between intense Facebook use and social appearance anxiety can contribute to understanding especially the anxiety. When psychological variables influencing social appearance anxiety are examined, impact of the social support should be taken into consideration (Hart, Rotondi, Souleymanov et al., 2015) It is thought that social share platforms like Facebook open a new road in individual's seeking and receiving support (Davis, Anthony, \& Pauls, 2015).

In conclusion, there are many dynamics influencing the Facebook use intensity. Social share platforms like Facebook offer a rich data source about many important topics in social sciences. In Facebook, we can observe various topics like people's online social interactions and relationships with others, personal interest areas, thoughts, beliefs, etc. with a few clicks (Guadagno, Loewald, Muscanell, Barth, Goodwin, \& Yang, 2013). User participation has gradually spread in social data processing systems like social media platforms, online communities, and media share platforms. In the meantime, user populations might change and social content of individual users might develop. This dynamism that is inherent in the nature of social data processing systems that has been working for a long time might influence how the members of a platform use and perceive it (Lampe, Ellison, \& Steinfield, 2008). For this reason, Facebook and the like social media platforms are among the topics that should be studied up to date. When the concerned literature is considered, main aim of this research is to examine the role of problematic Internet use, social appearance anxiety, and sense of belonging in the intensity of university students' Facebook use. It is hoped that this research would make a leading contribution to the literature due to being one of the first few studies about Facebook use intensity. 


\section{Method}

\subsection{Research Model}

One of the quantitative research models, relational screening is used in this research. In this model, analysis can be made in two ways. These analyses are relations that are obtained through correlation-type connections and comparison method (Karasar, 2014). In the research, the role of problematic Internet use, social appearance anxiety, and sense of belonging in university students' Facebook use intensity are examined.

\subsection{Participant (Subject) Characteristics}

Study group of the research is composed of 484 university students, 332 females (68.6\%) and 152 males (31.4\%), from the university in the Konya province, in 2017-2018 academic year.

\subsection{Sampling Procedures}

\subsubsection{Measures and Covariates}

In the research, in order to obtain demographic information, personal information form prepared by the researchers; to determine the level of problematic Internet use of university students, "The Problematic Internet Use Scale" developed by E. Ceyhan, A. Ceyhan, and Gürcan (2007); to determine the intensity of Facebook use, "The Facebook Intensity Scale" that is developed by Ellison et al. (2007), and is adapted to Turkish Culture by Öztemel and Traş (2017); to determine the sense of belonging, "General Belonging Scale" that is developed by Malone, Pillow, and Osman (2012), and is adapted to Turkish Culture by Duru (2015); to determine social appearance anxiety, "Social Appearance Anxiety Scale" that is developed by Hart et al. (2008), and is adapted to Turkish Culture by Doğan (2010) are used as data collection tools.

\section{1) Facebook Intensity Scale}

The Facebook Intensity Scale was developed by Ellison, Steinfield, and Lampe (2007) and adapted to Turkish by Öztemel and Traş (2017). It is a 5-point Likert-type scale ( $1=$ strongly disagree, $5=$ strongly agree) consisting of a total of 6 items (e.g., Facebook is a part of my daily activities). An exploratory factor analysis (EFA), Monte Carlo parallel analysis, and confirmatory factor analysis (CFA) were performed to assess the validity of the scale. The EFA revealed that the scale was a single-factor scale just like its original form and that this single factor explained $57 \%$ of the total variance. The result of the Monte Carlo parallel analysis test confirmed the single-factor structure of the scale. Regarding the scale's validity, the goodness of fit coefficients obtained from the CFA were $\chi 2=27,241, \mathrm{df}=9, \chi 2 / \mathrm{df}=3.027, \mathrm{GFI}=.99, \mathrm{CFI}=.95, \mathrm{AGFI}=.96, \mathrm{NFI}=.93$, RMSEA $=.075$ $(\mathrm{CI}=.042-.110)$. The single-factor structure of the scale was also confirmed by CFA. Higher scores obtained from the scale indicate more intensive Facebook use. Cronbach's alpha internal consistency coefficient for the original scale was .85 . and $\alpha=.84$ for the adapted version used in the current study.

2) The Problematic Internet Use Scale (PIUS)

PIUS is developed by E. Ceyhan, A. Ceyhan, and Gürcan (2007) in order to evaluate the levels of problematic Internet use of university students. The scale is 5 point Likert type, and ranges from "strongly agree" to "strongly disagree". It is composed of 33 items. In this scale, one can get 33 points at least, and 165 points at most. As the points get higher, it can be seen that individuals' Internet use gets unhealthier, influences their lives negatively, and creates a disposition to a pathological situation like Internet addiction. It is found that the scale is composed of three sub-factors as "negative aspects of the Internet", "social benefits/social comfort", and "excessive use". It is stated that these three factors together explain the variance of $48.96 \%$. Within the scope of the scale's reliability studies, Cronbach Alfa internal consistency coefficient is determined as $(\alpha) .94$. It is stated that article total score reliability coefficient ranges between .31 and $.70(\mathrm{p}<.001)$. Also, as a result of the comparison of scale scores in extreme groups, it is found that all of the items are important in the level of $\mathrm{p}<.001$. Retest reliability coefficient of the scale is 0.81 , and correlation between two parts of it is 0.83 .

\section{3) General Belongingness Scale}

The scale is composed of 12 items, developed by Malone, Pillow, and Osman (2012), and adapted to Turkish by Duru (2015). This scale evaluates sense of belonging in two dimensions as being accepted and being rejected. In order to evaluate levels of agreeing to scale items, 7 point Likert is used. High scores in the scale show that individuals' sense of belonging is high. Internal consistency coefficient of General Belongingness Scale is found as .92. Internal consistency coefficient of acceptation/inclusion sub-scale, and rejection/exclusion scale are .89, and .91 , respectively. Analyses show that 12 items concentrate on two factors having 6.67 and 1.44 eigenvalues, which compose the $67.53 \%$ of total variance. Tests that are made for scale's confirmative factor analysis support the model $(\mathrm{X} 2(53, \mathrm{~N}=202)=110.022,<.001 .(\mathrm{X} 2 / \mathrm{df}=2.076) . \mathrm{GFI}=.92, \mathrm{RMSEA}=.07(.05-.09), \mathrm{SRMR}=.04$, 
$\mathrm{CFI}=.96, \mathrm{TLI}=.95, \mathrm{RFI}=.91, \mathrm{NFI}=.93$.

4) Social Appearance Anxiety Scale (SAAS)

It was developed by Hart et al. (2008). It was adapted to Turkish by Doğan (2010). It is composed of 16 items. It is one-dimensional. High scores on the scale express that appearance anxiety is high. Confirmatory factor analysis results reveal that the scale shows good fit. Internal consistency coefficient of the scale is found as .93. This structure that is obtained as single factor according to the exploratory factor analysis explains the $53.4 \%$ of the total variance. The scale is 5 point Likert type grading ( $1=$ strongly disagree, $5=$ strongly agree).

\subsubsection{Research Design}

The scales that are used in the research are given to voluntary students within the class hours by researchers, as a single form. Before practice, information was given about the aim of the research and the scales were introduced. Practice time was about 20-25 minutes.

\subsection{Analyses}

Data obtained in this research is analyzed and evaluated with SPSS (20). In order to determine the relationships between variables, Pearson Moment Correlation coefficients are calculated. Also, in order to determine if Facebook intensity scores are predicted or not, multiple regression analysis is used.

\section{Results}

Table 1. Correlation between variables

\begin{tabular}{lcccc}
\hline & 1 & 2 & 3 & 4 \\
\cline { 2 - 4 } & & & \\
1. Facebook Intensity & - & $.27^{* *}$ & $-.21^{* *}$ & $.26^{* *}$ \\
2. PIUS & & - & $-.48^{* *}$ & $.43^{* *}$ \\
3. Belongingness & & & - & $-.47^{* *}$ \\
4. Social Appearance Anxiety & & & - \\
\hline
\end{tabular}

$* * \mathrm{p}<.01$.

As seen in Table 1, there is a significant and positive relationship between participants' score averages in The Facebook Intensity Scale, in The Problematic Internet Use (PIU) Scale $(\mathrm{p}<.01, \mathrm{r}=.27)$, and in The Social Appearance Anxiety (SAA) Scale $(\mathrm{p}<.01, \mathrm{r}=.26)$. Also, there is a significant and negative relationship between score averages in The Facebook Intensity Scale and in The General Belongingness Scale $(\mathrm{p}<.01, \mathrm{r}=-.21)$.

Table 2. Regression analysis results concerning Facebook intensity

\begin{tabular}{llcccc} 
& Variables & B & SE & $\beta$ & $\mathrm{t}$ \\
\cline { 2 - 7 } & Constant & 7.422 & 3.075 & & 2.414 \\
& Problematic Internet Use & .059 & .017 & .175 & $3.430^{*}$ \\
& Sense of Belonging & -.032 & .031 & -.055 & -1.037 \\
$\mathrm{R}=.31, \mathrm{R} 2=.10, \mathrm{~F}=17.445, \mathrm{p}<.001,{ }^{*} \mathrm{p}<.05$. & & & & &
\end{tabular}

In Table 2, regression analysis results concerning The Facebook Intensity Scale are seen. When the table is examined it can be seen that all variables together that are stated as predictor variables predict The Facebook Intensity Scale on a significant level $(\mathrm{R}=.31, \mathrm{R} 2=.10, \mathrm{~F}=17.445, \mathrm{p}<.001)$, and that explains $10 \%$ of the total variance concerning The Facebook Intensity Scale. When the concerned $\beta$ values are examined, it is seen that the strongest predictor is The Problematic Internet Use Scale $(\beta=.175)$. After this, The Social Appearance Anxiety Scale $(\beta=.155)$ comes. The General Belongingness Scale is not a significant predictor.

\section{Discussion}

In this research, a significant relationship between university students' social appearance anxiety and Facebook use intensity. Also, one of the significant predictors of Facebook use intensity is social appearance anxiety. Individuals' feelings about Facebook can be related to their emotions about their appearances. Especially, individuals who make emotional investment in Facebook can be more interested in their appearances. Facebook is a highly visual social media platform. For the ones who are interested more particularly in their appearances it can 
be a place in which they can continuously "work on" by managing their images virtually (for example, by publishing their pictures). Also, the ones who have less emotional bonds with Facebook might have more positive views about their appearances (Rutledge, Gillmor, \& Gillen, 2013). It is logical to anticipate that being continuously exposed to photos of others makes comparisons based on appearance easier, and accordingly, influences the body image of users (Rutledge, Gillmor, \& Gillen, 2013). Social appearance anxiety can be evaluated as a result of the negative body image about the individual's appearance and body (Doğan, 2010). Facebook is a widely used platform that offers users opportunity of a large-scaled social comparison with peers, families, and media. For this reason, it can be a new and important way to research in the field of body negativity (Stronge, Greaves, Milojev, West-Newman, Barlow, \& Sibley, 2015). In a research conducted by Tiggemann and Slater (2013), it is found that body image anxieties of adolescent girls who use Facebook are higher in proportion to the ones who do not use Facebook. Smith, Hames, and Joiner (2013) find a significant and positive relationship between excessive Facebook use and body dissatisfaction. In their studies conducted on university students, Eckler, Kalyango, and Paasch (2017) find a significant and positive relationship between the time they spent on Facebook and, negative thoughts about their bodies and paying attention to others' physical appearance. In the study, conducted on female university students by Puglia (2017) it is determined that participants who use Facebook on a high level display less body satisfaction in proportion to the ones who use Facebook less. In their studies, conducted on university students, Manago, Ward, Lem, Reed, and Seabroo (2014) find a positive and significant relationship between Facebook use and body consciousness. It is seen that findings of this research match up with the previous studies.

In this research, a significant relationship is found between problematic Internet use of university students and Facebook use intensity. Also, one of the significant predictors of Facebook use intensity is problematic Internet use. Because Facebook is a platform on the Internet, it can be said that there is similarities between Internet use and Facebook use (Assunçao \& Matos, 2017). As the availability of social media networks like Facebook increases, it is possible that use of these would continue to contribute to the problematic uses (Kittinger, Correia $\&$ Irons, 2012). In the study by Abarado (2015) it is found that there is a positive and significant relationship between university students' average scores in The Facebook Intensity Scale and in The Internet Activity Scale. Yu et al. (2012) find a positive relationship between Internet addiction and Facebook use. Carmody (2012) find that there is a relationship between Internet addiction and Facebook use, in the study conducted on university students. Kittinger et al. (2012) find a significant relationship between problematic Internet use and Facebook use in a study conducted on 281 postgraduate students. Also, Tras and Oztemel (2019) find there are significant positive correlations between Facebook intensity scores and duration of internet use $(r=.08 ; \mathrm{p}<.05)$ in their study. Findings of this research match up with the previous studies.

In this research, a significant and negative relationship is found between university students' Facebook use intensity and sense of belonging. Knowles, Haycock, and Shaikh (2015), too find belonging needs predicted Facebook use in their research. Meeting sense of belonging need enables features like self-esteem, self-confidence etc. to show up (Maslow, 1954). Suler (1999) states that individuals use the Internet in order to meet certain needs, and one of these needs is sense of belonging. Because individuals spend too much time online, it is supposed that they would spend too much energy in order to form a relationship and support network via other users, and experience the feeling of belonging to a community (Moody, 2001). Facebook ensure an important resource for fulfilling the elementary human need for social connection (Kross et al., 2013). Individuals who have lower levels of belonging feeling might try to meet their sense of belonging need via social media platforms like Facebook.

In this research, Facebook Intensity is studied only on university students. In future researches, age range of study group can be kept as wider. Social appearance anxiety has contributed to the prediction of Facebook intensity. Facebook enables users to change how they are figured out by others by editing their profiles (Dickstein-Fischer, 2013). The individuals who have social appearance anxiety might have intensely use Facebook due to the possibility of portraying themselves at will. For this reason, influence of strategies for coping with body image on Facebook use might be addressed apart from social appearance anxiety. Also, addressing different sub-types of social anxiety as the predictor of university students' Facebook use might contribute to better understanding of Facebook use.

\section{References}

Abarado, M. L. (2015). A study of the relationships between self-esteem, narcissism and social anxiety with Facebook and Internet use among college students (Bachelor thesis, Dublin Business School).

Akbaba, S. (2005). Sosyal bütünleşmenin psiko-sosyal temelleri. Atatürk Üniversitesi Kazım Karabekir Eğitim Fakültesi Dergisi, 11, 19-25. 
Al-Dheleai, Y. M., \& Tasir, Z. (2015). Facebook and education: students' privacy concerns. International Education Studies, 8(13), 22-26. https://doi.org/10.5539/ies.v8n13p22

Alptekin, D. (2012). Toplumsal aidiyet ve gençlik. Ankara: Nobel.

Altındiş, A., Altındiş, S., Aslan, F. G., Așıcı, N., İnci, M. B., Ekerbiçer, H. Ç., \& Tokaç, M. (2017). Sosyal Medya Ağları Ve Sosyal Görünüm Anksiyetesi. International Journal Of Social Science, 64 (3), 227-235. https://doi.org/10.9761/JASSS7353

Anandarajan, M., Simmers, C. A., \& Teo, T. S. (2014). The Internet and workplace transformation: An introduction. In The internet and workplace transformation (pp. 13-22). Routledge.

Anderson, K. J. (2001). Internet use among college students: an exploratory study. Journal of American College Health, 50, 21-26. https://doi.org/10.1080/07448480109595707

Andreassen, C. S., Billieux, J., Griffiths, M. D., Kuss, D. J., Demetrovics, Z., Mazzoni, E., \& Pallesen, S. (2016). The relationship between addictive use of social media and video games and symptoms of psychiatric disorders: A large-scale cross-sectional study. Psychology of Addictive Behaviors, 30(2), 252. https://doi.org/10.1037/adb0000160

Assunção, R. S., \& Matos, P. M. (2017). The Generalized Problematic Internet Use Scale 2: Validation and test of the model to Facebook use. Journal of adolescence, 54, 51-59. https://doi.org/10.1016/j.adolescence.2016.11.007

Beard, K. W. (2005). Internet addiction: A review of current assessment techniques and potential assessment questions. CyberPsychology \& Behavior, 8(1), 7-14. https://doi.org/10.1089/cpb.2005.8.7

Błachnio, A., \& Przepiorka, A. (2016). Personality and positive orientation in Internet and Facebook addiction. An empirical report from Poland. Computers in Human Behavior, 59, 230e-236. https://doi.org/10.1016/j.chb.2016.02.018

Blachnio, A., Przepiorka, A., Senol-Durak, E., Durak, M., \& Sherstyuk, L. (2017). The role of personality traits in Facebook and Internet addictions: A study on Polish, Turkish, and Ukrainian samples. Computers in Human Behavior, 68, 269-275. https://doi.org/10.1016/j.chb.2016.11.037

Boyd, D., \& Ellison, N. (2007). Social Network Sites: Definition, History, and Scholarship. Journal of Computer-Mediated Communication, 13(1), 210-230. https://doi.org/10.1111/j.1083-6101.2007.00393.x

Brown, P. (2012). The Legend of Zelda and Abraham Maslow's Theoryof Needs: A Social-Psychological Study of the Computer Game and its Players (Doctoral dissertation, The University of Manchester, United Kingdom).

Burger, J. M. (2006). Kişilik (çev. Deniz E. Sarığlu). İstanbul: Kaktüs Yayınları.

Campisi, J., Bynog, P., McGehee, H., Oakland, J. C., Quirk, S., Taga, C., \& Taylor, M. (2012). Facebook, stress, and incidence of upper respiratory infection in undergraduate college students. Cyberpsychology, Behavior, and Social Networking, 15(12), 675-681. https://doi.org/10.1089/cyber.2012.0156

Caplan, S. E. (2007). Relations among loneliness, social anxiety, and problematic Internet use. Cyberpsychology \& behavior, 10(2), 234-242. https://doi.org/10.1089/cpb.2006.9963

Carmody, C. L. (2012). Internet addiction: Just Facebook me! The role of social networking sites in internet addiction. Computer Technology and Application, 3(3), 262-267.

Ceyhan, A. A. (2011). University Students' Problematic Internet Use and Communication Skills According to the Internet Use Purposes. Educational Sciences: Theory and Practice, 11(1), 69-77.

Ceyhan, E., Ceyhan, A. A., \& Gürcan, A. (2007). Problemli internet kullanımı ölçeğinin geçerlik ve güvenirlik çalışmaları. Kuram ve Uygulamada Eğitim Bilimleri Dergisi, 7(1), 387-416.

Cüceloğlu, D. (2002). Insan ve Davranışı. Remzi Kitapevi: İstanbul.

Davis, R. A. (2001). A cognitive-behavioral model of pathological Internet use. Computers in human behavior, 17(2), 187-195. https://doi.org/10.1016/S0747-5632(00)00041-8

De Vries, H. T., Nakamae, T., Fukui, K., Denys, D., \& Narumoto, J. (2018). Problematic internetuse and psychiatric co-morbidity in a population of Japanese adult psychiatric patients. BMC psychiatry, 18(1), 9. https://doi.org/10.1186/s12888-018-1588-z

Dickstein-Fischer, L. (2013). Facebook use in relation to gender, introversion-extroversion, and sense of 
belonging among college students (Doctoral dissertation, Northeastern University).

Doğan, T. (2010). Sosyal Görünüş Kaygısı Ölçeği’nin (SGKÖ) Türkçe uyarlaması: geçerlik ve güvenirlik çalışması. Hacettepe Üniversitesi Ĕ̈itim Fakültesi Dergisi, 39(39), 151-159.

Duru, E. (2015). Genel aidiyet ölçeğinin psikometrik özellikleri: Geçerlik ve güvenirlik çalışması. Türk Psikolojik Danışma ve Rehberlik Dergisi, 5(44). https://doi.org/10.12780/uusbd.00234

Eckler, P., Kalyango, Y., \& Paasch, E. (2017). Facebook use and negative body image among US college women. Women \& health, 57(2), 249-267. https://doi.org/10.1080/03630242.2016.1159268

Ellison, N. B., Steinfield, C., \& Lampe, C. (2007). The benefits of Facebook "friends": Social capital and college students' use of online social network sites. Journal of Computer-Mediated Communication, 12(4), 1143-1168. https://doi.org/10.1111/j.1083-6101.2007.00367.x

Foley, P. (2004). Does the Internet help to overcome social exclusion. Electronic Journal of e-government, 2(2), 139-146.

Gangadharbatla, H. (2008). Facebook me: Collective self-esteem, need to belong, and internet self-efficacy as predictors of the iGeneration's attitudes toward social networking sites. Journal of interactive advertising, 8(2), 5-15. https://doi.org/10.1080/15252019.2008.10722138

Gouya, S. M. A, Nia, Z. M., Mirdar, H., \& Zadeh, Z. B. (2014). The Role of Social Physique Anxiety in leisure time Physical activity of Youngers. International Research Journal of Applied and Basic Sciences, 8(11), 1945-1949.

Greenfield, D. N. (1999). Psychological characteristics of compulsive Internet use: A preliminary analysis. Cyberpsychology \& behavior, 2(5), 403-412. https://doi.org/10.1089/cpb.1999.2.403

Grieve, R., Indian, M., Witteveen, K., Tolan, G. A., \& Marrington, J. (2013). Face-to-face or Facebook: Can social connectedness be derived online? Computers in human behavior, 29(3), 604-609. https://doi.org/10.1016/j.chb.2012.11.017

Guadagno, R. E., Loewald, T. A., Muscanell, N. L., Barth, J. M., Goodwin, M. K., \& Yang, Y. (2013). Facebook history collector: A new method for directly collecting data from Facebook. International Journal of Interactive Communication Systems and Technologies (IJICST), 3(1), 57-67. https://doi.org/10.4018/ijicst.2013010105

Hagerty, B. M., Lynch-Sauer, J., Patusky, K. L., Bouwsema, M., \& Collier, P. (1992). Sense of belonging: A vital mental health concept. Archives of psychiatric nursing, 6(3), 172-177. https://doi.org/10.1016/0883-9417(92)90028-H

Hart, T. A., Flora, D. B., Palyo, S. A., Fresco, D. M., Holle, C., \& Heimberg, R. G. (2008). Development and examination of the social appearance anxiety scale. Assessment, 15(1), 48-59. https://doi.org/10.1177/1073191107306673

Hart, T. A., Rotondi, N. K., Souleymanov, R., \& Brennan, D. J. (2015). Psychometric properties of the Social Appearance Anxiety Scale among Canadian gay and bisexual men of color. Psychology of Sexual Orientation and Gender Diversity, 2(4), 470. https://doi.org/10.1037/sgd0000140

Hughes, D. J., Rowe, M., Batey, M., \& Lee, A. (2012). A tale of two sites: Twitter vs. Facebook and the personality predictors of social media usage. Computers in Human Behavior, 28(2), 561-569.

Karasar, N. (2014). Bilimsel araştırma yöntemi. Ankara: Nobel Yayın Dağıtım.

Kılıç, N., Mammadov, M., Koçhan, K., \& Aypay, A. (2018). The predictive power of general self-efficacy beliefs and body images of university students on resilience. Hacettepe University Journal of Education, Advance online publication.

Kim, H. K., \& Davis, K. E. (2009). Toward a comprehensive theory of problematic Internet use: Evaluating the role of self-esteem, anxiety, flow, and the self-rated importance of Internet activities. Computers in Human Behavior, 25(2), 490-500. https://doi.org/10.1016/j.chb.2008.11.001

Kittinger, R., Correia, C. J., \& Irons, J. G. (2012). Relationship between Facebook use and problematic Internet use among college students. Cyberpsychology, Behavior, and Social Networking, 15(6), 324-327. https://doi.org/10.1089/cyber.2010.0410

Knowles, M. L., Haycock, N., \& Shaikh, I. (2015). Does Facebook magnify or mitigate threats to belonging? Social Psychology. https://doi.org/10.1027/1864-9335/a000246 
Kross, E., Verduyn, P., Demiralp, E., Park, J., Lee, D. S., Lin, N., ... \& Ybarra, O. (2013). Facebook use predicts declines in subjective well-being in young adults. PloS one, 8(8), e69841. https://doi.org/10.1371/journal.pone.0069841

Kuss, D. J., Griffiths, M. D., Karila, L., \& Billieux, J. (2014). Internet addiction: a systematic review of epidemiological research for the last decade. Current pharmaceutical design, 20(25), 4026-4052. https://doi.org/10.2174/13816128113199990617

Lampe, C., Ellison, N. B., \& Steinfield, C. (2008, November). Changes in use and perception of Facebook. In Proceedings of the 2008 ACM conference on Computer supported cooperative work (pp. 721-730). ACM. ttps://doi.org/10.1145/1460563.1460675

Leake, V. S. (2007). Personal, familial, and systemic factors associated with family belonging for stepfamily adolescents. Journal of Divorce \& Remarriage, 47(1-2), 135-155. https://doi.org/10.1300/J087v47n01_08

Malone, G. P., Pillow, D. R., \& Osman, A. (2012). The general belongingness scale (GBS): Assessing achieved belongingness. Personality and Individual Differences, 52(3), 311-316. https://doi.org/10.1016/j.paid.2011.10.027

Manago, A. M., Ward, L. M., Lemm, K. M., Reed, L., \& Seabrook, R. (2015). Facebook involvement, objectified body consciousness, body shame, and sexual assertiveness in college women and men. Sex Roles, 72(1-2), 1-14. https://doi.org/10.1007/s11199-014-0441-1

Maslow, A. H. (1954). Motivation and Personality. Harper \& Row, Publishers.

McCord, B., Rodebaugh, T. L., \& Levinson, C. A. (2014). Facebook: Social uses and anxiety. Computers in Human Behavior, 34, 23-27. https://doi.org/10.1016/j.chb.2014.01.020

Moody, E. J. (2001). Internet use and its relationship to loneliness. CyberPsychology \& Behavior, 4(3), 393-401. https://doi.org/10.1089/109493101300210303

Morahan-Martin, J., \& Schumacher, P. (2003). Loneliness and social uses of the Internet. Computers in Human Behavior, 19(6), 659-671. https://doi.org/10.1016/S0747-5632(03)00040-2

Nesi, J., \& Prinstein, M. J. (2015). Using social media for social comparison and feedback-seeking: gender and popularity moderate associations with depressive symptoms. Journal of Abnormal Child Psychology, 43(8), 1427-1438. https://doi.org/10.1007/s10802-015-0020-0

Özkan, F. (2015). Öğrencilerin Okullarının İmajına İlişkin Alglları ve Aidiyet Düzeyleri (İstanbul Eyüp İlçesi Örneği) (Doctoral Dissertation, İstanbul Aydın Üniversitesi Sosyal Bilimler Enstitüsü).

Özteke-Kozan, H. İ., \& Hamarta, E. (2017). Beliren yetişkinlikte beden imgesi: Bağlanma ve sosyal görünüş kaygısının rolü. Türk Psikolojik Danışma ve Rehberlik Dergisi, 7(48), 63-81.

Öztemel, K., \& Traş, Z. (2017). Facebook Yoğunluğu Ölçeği'nin (FYÖ) Türkçe’ye uyarlanması: Faktör yapısı ve güvenirliğinin incelenmesi. Türk Eğitim Bilimleri Dergisi, 15(2), 91-101.

Przepiorka, A., \& Blachnio, A. (2016). Time perspective in Internet and Facebook addiction. Computers in Human Behavior, 60, 13-18. https://doi.org/10.1016/j.chb.2016.02.045

Puglia, D. R. (2017). Social Media Use and Its Impact on Body Image: The Effects of Body Comparison Tendency, Motivation for Social Media Use, and Social Media Platform on Body Esteem in Young Women (Doctoral dissertation, The University of North Carolina at Chapel Hill).

Rutledge, C. M., Gillmor, K. L., \& Gillen, M. M. (2013). Does this profile picture make me look fat? Facebook and body image in college students. Psychology of Popular Media Culture, 2(4), 251. https://doi.org/10.1037/ppm0000011

Santrock, J. W. (2012). Yaşam boyu gelişim (Çev.ed. Galip Yüksel). Ankara: Nobel Yayın.

Shapira, N. A., Goldsmith, T. D., Keck, P. E., Khosla, U. M., \& McElroy, S. L. (2000). Psychiatric features of individuals with problematic internet use. Journal of Affective Disorders, 57(1-3), 267-272. https://doi.org/10.1016/S0165-0327(99)00107-X

Smith, A. R., Hames, J. L., \& Joiner, T. E. (2013). Status update: Maladaptive Facebook usage predicts increases in body dissatisfaction and bulimic symptoms. Journal of affective disorders, 149(1), 235-240. https://doi.org/10.1016/j.jad.2013.01.032

Stieger, S., Burger, C., Bohn, M., \& Voracek, M. (2013). Who commits virtual identity suicide? Differences in privacy concerns, internet addiction, and personality between Facebook users and quitters. Cyberpsychology, 
Behavior, and Social Networking, 16(9), 629-634. https://doi.org/10.1089/cyber.2012.0323

Stronge, S., Greaves, L. M., Milojev, P., West-Newman, T., Barlow, F. K., \& Sibley, C. G. (2015). Facebook is linked to body dissatisfaction: Comparing users and non-users. Sex Roles, 73(5-6), 200-213. https://doi.org/10.1007/s11199-015-0517-6

Suler, J. R. (1999). To get what you need: healthy and pathological Internet use. CyberPsychology \& Behavior, 2(5), 385-393. https://doi.org/10.1089/cpb.1999.2.385

Thatcher, A., \& Goolam, S. (2005). Development and psychometric properties of the Problematic Internet Use Questionnaire. South African Journal of Psychology, 35(4), 793-809. https://doi.org/10.1177/008124630503500410

Tiggemann, M., \& Slater, A. (2013). NetGirls: The Internet, Facebook, and body image concern in adolescent girls. International Journal of Eating Disorders, 46(6), 630-633. https://doi.org/10.1002/eat.22141

Tras, Z., \& Öztemel, K. (2019). Examining the Relationships between Facebook Intensity, Fear of Missing Out, and Smartphone Addiction. Addicta: The Turkish Journal On Addictions, 6(1), 91-113. https://doi.org/10.15805/addicta.2019.6.1.0063

Ülkü, H. (2017). Gençlerde sosyal görünüş kaygısı ile sosyal anksiyete arasındaki ilişsinin toplumsal cinsiyet bağlamında incelenmesi. Yayınlanmamış Yüksek Lisans Tezi, Üsküdar Üniversitesi/Sosyal Bilimler Enstitüsü, İstanbul.

Vannucci, A., Flannery, K. M., \& Ohannessian, C. M. (2017). Social media use and anxiety in emerging adults. Journal of affective disorders, 207, 163-166. https://doi.org/10.1016/j.jad.2016.08.040

Watson, J. C. (2005) Internet addiction diagnosis and assessment: Implications for counselors. Journal of Professional Counseling: Practice, Theory, \& Research, 33, 17-30. https://doi.org/10.1080/15566382.2005.12033815

Young, K. (1996). Internet addiction: The emergence of a new clinical disorder. CyberPsychology \& Behavior, 3, 237-244. https://doi.org/10.1089/cpb.1998.1.237

Young, K. S. (1999). Internet addiction: symptoms, evaluation and treatment. Innovations in clinical practice: A source book, 17, 19-31.

Yu, S. C., Hsu, W. H., Yu, M. N., \& Hsu, H. Y. (2012). Is the use of social networking sites correlated with internet addiction? Facebook use among Taiwanese college students. World Academy of Science, Engineering and Technology, 68, 1659-1661.

\section{Copyrights}

Copyright for this article is retained by the author(s), with first publication rights granted to the journal.

This is an open-access article distributed under the terms and conditions of the Creative Commons Attribution license (http://creativecommons.org/licenses/by/4.0/). 